Cadernos de Literatura em Tradução, n. 5, p. 59-75

\title{
Quem encontra algo procurou mal: dez poemas de Rutger Kopland
}

Jeroen Dewulf

"Wie wat vindt heeft slecht gezocht" - "Quem encontra algo procurou mal", essa frase não é apenas o título de uma colectânea de Rutger Kopland que saiu em 1972, é também uma frase que caracteriza a sua maneira de escrever e de pensar poesia. Rutger Kopland (pseudônimo de Rutger Hendrik van den Hoofdakker) nasceu em Goor, nos Países-Baixos, em 4 de Agosto de 1934. Kopland descobriu o seu talento para a poesia ainda quando era estudante de medicina em Groningen. Depois de formado, continuou a escrever poesia paralelamente ao seu trabalho como médico, cientista e, a partir de 1983, professor de Biopsiquiatria na universidade onde se formou. É um dos mais conceituados poetas holandeses contemporâneos, distinguido, em 1988, com o prestigioso prémio P.C. Hooft. $O$ seu sucesso reflecte-se também na venda dos seus livros - nenhum poeta holandês vende tanto como Kopland - e nas traduções em mais de trinta línguas, das quais citamos as edições inglesas: An Empty Place to Stay and Other Selected Poems (Twin Peaks Press, San Francisco, 1977), The Prospect and the River (Jackson's Arm, London, 1987), A World Beyond Myself (Enitharmon Press, London, 1991) e francesas Songer à partir (Gallimard, Paris, 1986) e Souvenirs de l'inconnu (Gallimard, Paris, 1998).

Apesar de Kopland pretender distinguir claramente entre a sua profissão como cientista e a sua poesia, o crítico literário Remco 
DEWULF, Jeroen. Quem encontra algo procurou mal: dez poemas de Rutger Kopland.

Ekkers sublinha que a fonte das duas atividades é a mesma, nomeadamente, uma curiosidade pela estrutura da realidade. Tanto na ciência como na arte, procura-se uma ligação entre aquilo de que não se sabia que existia. (Ekkers 1997:8) Assim, voltamos à palavra-chave "procurar", um conceito bem presente na obra de Kopland. Trata-se, por um lado, de uma procura pela palavra certa, como, por exemplo, se vê no título da sua poetologia de 1998 "Mooi, maar dat is het woord niet" - "Bonito, mas não é esta a palavra". É também uma procura pela formulação mais adequada para poder exprimir uma idéia, um pensamento ou um conceito. Veja-se, por exemplo, a contínua repetição da frase "o que quero dizer é", que praticamente faz recomeçar três vezes o poema "Wat is geluk?" - "O que é felicidade" de 1997.

Rutger Kopland não é um poeta "cômodo". A sua obra não proporciona ao leitor nenhum tipo de conforto; ela parte do princípio de que cabe a cada indivíduo determinar a sua própria existência e de que, nessa tarefa, está rigorosamente só. Contudo, a melancolia Koplandiana é profundamente irônica. Kopland foge de todo tipo de ideias bombásticas, o seu pensamento segue um olhar irônico sobre a vida quotidiana, o que faz com que os seus poemas sejam muito leves, tão leves que quase escondem a sempre presente desilusão. Apesar de os seus poemas terem um estilo simples e ligeiro, é uma poesia que nos cativa e para a qual o poeta flamengo Herman de Conick utilizou a palavra "misteriosa" (Conick 1970:70). Um mistério que talvez esteja ligado à eterna procura de um certo sentido na vida; um certo sentido e não um sentido certo, pois, quem encontra algo, diz Kopland, procurou mal. Ou seja, o encontrar não é apenas impossível, é até indesejável. Deste modo, Kopland indica que o verdadeiro sentido da vida está apenas no procurar. Trata-se de um pensamento que nos leva para bem perto do niilismo, mas em vez de afirmar que a vida é sem sentido, Kopland parece mais inclinar para a idéia de uma vida livre de sentido, isto é, uma vida em que cada um/uma tem a liberdade de fazer com a sua existência o que quiser, mes- 
mo sabendo que na sua procura estará sempre só, mesmo sabendo que nunca encontrará aquilo que deseja encontrar. Verdades absolutas são rejeitadas por Kopland, quando no seu poema de 1969 "De macht van het evangelie" - "A força do evangelho", o senhor the bata à porta, não é ele que segue o senhor, mas é o próprio senhor que acaba por pedir perdão de lhe ter incomodado. O conceito da verdade aparece-nos assim no sentido nietzscheano, da verdade como uma metáfora, como algo que até se pode tentar captar em palavras, mas para o qual nunca ninguém conseguirá encontrar a última palavra. E olhando para aquilo que fizeram aqueles que julgavam ter encontrado a verdade, só podemos dar razão a Kopland quando afirma: "Quem encontra algo procurou mal".

Apresentamos aqui uma tradução para o português de dez poemas seus. Da coletânea Het orgeltje van yesterday ("O pequeno órgão de yesterday", 1968) escolhemos os poemas "Juffrouw $A^{\prime \prime}$ ("A jovem senhora A"), "Zijn jas" ("O seu casaco") e "De dokter van Jantje" ("O médico do Joãozinho"). Os poemas "De macht van het evangelie" ("A força do evangelho"), "Een moeder" ("Uma mãe") e o seu poema mais famoso "Jonge sla" ("Alface nova") foram tirados da sua obra Alles op de fiets ("Tudo de bicicleta", 1969). Seguem-se os poemas "Vertrek van dochters" ("Quando partem as filhas") de Dit uitzicht ("Esta vista", 1982), "Zelfportret" ("Auto-retrato") de Dankzii de dingen ("Graças às coisas", 1989), "Oude gezichten" ("Rostos velhos") de Geduldig gereedschap ("Utensílios pacientes", 1993). Concluímos com o poema que o próprio Rutger Kupland considera um dos seus preferidos: "Wat is geluk" ("O que é felicidade") da sua mais recente colectânea de poesia Tot het ons loslaat ("Até que nos largue", 1997). Agradecese a Márcio $A$. Vianna $\mathrm{F}^{\circ}$ por ter contribuído na revisão e a Arie Pos e Bas Pauw pelo seu apoio na busca da bibliografia. Os direitos dos poemas de Kopland estão com a editora G.A. van Oorschot (Amesterdã). 
DEWULF, Jeroen. Quem encontra algo procurou mal: dez poemas de Rutger Kopland.

\section{JUFFROUW A}

Op 19 september, een nevelige negentiende, stapte juffrouw $A$ aan de verkeerde kan van haar scheepje Steeds Tevreeden in het Meppelerdiep.

Het was al koud, zij had de kachel niet aan kunnen kriigen, haar oude moeder was gestorven, alles roestte en knarste, vanuit haar kombuis leken god en sociale zaken niet te bereiken. Zij ging van boord

\section{A JOVEM SENHORA A}

No dia 19 de Setembro, um dezanove nublado, a jovem senhora $A$ saiu do lado errado do seu barquinho Sempre Contente no rio Meppelerdiep.

Já fazia frio, ela não tinha conseguido acender o fogão, a sua velha mãe morrera, tudo enferrujava e rangia, de dentro da sua cozinha, deus e a segurança social pareciam-lhe inacessíveis.

Ela desembarcou. 


\section{ZIJN JAS}

Mijn vader J was nog maar net gestorven toen mijn moeder $A$ zijn nieuwe regenjas voorzichtig van de kapstok nam. Pas eens, zei ze, hij was er zo trots op.

Daar stond ik dan en voelde aan de mouwen en bij het sluiten van de knopen hoe dood hij was en hoe ver weg mijn jeugd. Oud en zwak zou ik worden, in deze plooien zou mijn huid gaan hangen om mijn knoken.

\section{A SUA GABARDINA}

Logo que o meu pai J

morreu, a minha mãe A apanhou cuidadosamente a nova gabardina do bengaleiro. Experimenta, disse, ele tinha tanto brio nela.

Então lá estava eu a sentir nas mangas e ao fechar os botões o quanto ele estava morto e quanto a minha juventude estava distante. Eu teria de ficar velho e fraco, nestas dobras a minha pele viria a ficar pendurada em torno dos ossos. 


\section{DE MACHT VAN HET EVANGELIE}

De heer die de deur open deed

en die ik vriendeliik vroeg

om hem dicht te laten,

deed dit niet. Ik sloot

de deur. Eerste waarschuwing.

De heer deed de deur weer open

en toen ik hem vroeg dan ten-

minste zijn mond dicht te doen,

deed hij dit niet. Ik sloot

de deur. Tweede waarschuwing.

De heer probeerde weer de deur open te doen, maar omdat ik er krachtig tegenaan was gaan staan, lukte dit niet. Ik hield de deur dicht. Derde waarschuwing.

De heer ramde de deur toen open en omdat ik even op zij was gegaan viel de heer op ziin knieën voor mijn voeten. Ik sloot de deur. Vierde waarschuwing.

De heer was grauw en zocht ruzie, maar toen ik vriendelijk zei dat ik niet hier maar later vreselijk zou worden gestraft, vroeg hij vergeving en verdween door de deur, die ik voor hem open hield. 


\section{A FORÇA DO EVANGELHO}

O senhor que abriu a porta

e a quem gentilmente pedi

que a deixasse fechada, não o fez. Eu fechei

a porta. Primeiro aviso.

senhor abriu novamente a porta e quando the pedi para ao

menos se calar,

ele não o fez. Eu fechei

a porta. Segundo aviso.

O senhor tentou abrir a porta

novamente, mas como eu a

segurei com força,

ele não conseguiu. Eu mantive

a porta fechada. Terceiro aviso.

O senhor então arrombou a porta

e como tinha-me afastado dela

o senhor caiu de joelhos

aos meus pés. Eu fechei

a porta. Quarto aviso.

O senhor foi rude e queria brigar,

mas quando gentilmente the disse que eu não seria castigado aqui de forma atroz, mas depois, ele pediu perdão

e desapareceu pela porta, que eu

mantive aberta para ele. 
DEWULF, Jeroen. Quem encontra algo procurou mal: dez poemas de Rutger Kopland.

\section{EEN MOEDER}

loopt langzaam naar haar kind om

het niet te laten schrikken,

pakt het voorzichtig op om

het niet te beschadigen,

slaat dan keihard.

\section{UMA MÃE}

anda lentamente em direcção ao seu filho para não o assustar,

levanta-o cuidadosamente para

não o danificar,

depois bate com toda a força. 


\section{JONGE SLA}

Alles kan ik verdragen, het verdorren van bonen, stervende bloemen, het hoekje aardappelen kan ik met droge ogen zien rooien, daar ben ik werkelijk hard in.

Maar jonge sla in September, net geplant, slap nog, in vochtige bedjes, nee.

\section{ALFACE NOVA}

Suporto qualquer coisa, os feijões que estão a secar, as flores a morrer, no cantinho das batatas posso vê-las ser colhidas com os olhos secos, para essas coisas é verdade que sou mesmo duro.

Mas alface nova em Setembro, recém plantada, fraca ainda, em canteiros húmidos, isso não. 
DEWULF, Jeroen. Quem encontra algo procurou mal: dez poemas de Rutger Kopland.

\section{VERTREK VAN DOCHTERS}

Ze moesten inderdaad gaan, ik had het gezien aan hun gezichten die langzaam veranderden van die van kinderen in die van vrienden, van die van vroeger in die van nu.

En gevoeld en geroken als ze me kusten, een huid en een haar die niet meer voor mij waren bedoeld, niet zoals vroeger, toen we de tiid nog hadden.

Er was in ons huis een wereld van verlangen, geluk, piin en verdriet gegroeid, in hun kamers waarin ze verzamelden wat ze mee zouden nemen, hun herinneringen.

Nu ze weg zijn kijk ik uit hun ramen en zie precies dat zelfde vitzicht, precies die zelfde wereld van twintig jaar her, toen ik hier kwam wonen. 


\section{QUANDO PARTEM AS FILHAS}

Elas tinham mesmo de ir, vi-o nos seus rostos que se transformavam lentamente de rostos de crianças em rostos de amigas, de rostos de outrora nos rostos de agora.

E senti e cheirei, quando me beijaram, uma pele e uns cabelos que já não eram feitos para mim, não como antigamente, quando ainda tínhamos o tempo para nós.

Na nossa casa, formara-se um mundo de desejos, felicidade, dor e tristeza, nos seus quartos, onde juntavam o que iam levar, as suas recordações.

Agora que já partiram, olho pelas suas janelas e vejo precisamente aquela mesma paisagem, aquele mesmo mundo de vinte anos atrás, quando cá vim morar. 
DEWULF, Jeroen. Quem encontra algo procurou mal: dez poemas de Rutger Kopland.

\section{DE DOKTER VAN JANTJE}

De dokter ziet hoe de moeder haar zakdoekje in haar handen knelt. Hij kijkt naar haar handen, naar het schort waar de mantel openvalt, dan weg naar briefopener, papieren.

Ze zegt: ik heb liever dat $\mathrm{u}$ het vertelt.

\section{O MÉDICO DO JOÃOZINHO}

O médico vê como a mãe está a apertar o lenço nas mãos.

Ele olha para aquelas mãos, para a saia onde o sobretudo a deixa à mostra, desvia o olhar para corta-papel, papéis. Ela diz: prefiro que o doutor me conte. 


\section{OUDE GEZICHTEN}

Oude vrouwen, zij kunnen soms even glimlachen, even gezichten hebben als oude schilderijen.

Ineens weet ik hoe mooi zij zijn geweest, hoe ik naar hen heb verlangd.

Maar wat terugkeert in hun gezichten is voorbii, oud goudgeel licht

over die mooie wereld die er nog is maar alleen omdat zii er was.

\section{ROSTOS VELHOS}

Mulheres velhas, elas podem até sorrir por instantes, por instantes ter rostos como velhas pinturas

De repente sei o quanto foram bonitas, quanto as desejei.

Mas o que os seus rostos trazem de volta é passado, velha luz dourada.

a iluminar aquele belo mundo que ainda existe mas apenas por ter já existido. 
DEWULF, Jeroen. Quem encontra algo procurou mal: dez poemas de Rutger Kopland.

\section{ZELFPORTRET}

Zoals de hoge ramen van dit huis, zo moet het zijn, zoals nu.

Het is avond, daar beneden drijven wat eenden op de vijver, daar begint in het gras het pad zijn langzame boog omhoog door het woud, rood als oud bloed, en boven de heuvel de hemel, grauw van sneeuw, nevel en rook. Het kwaakt, schreeuwt, geurt naar vochtig blad en houtvuur, het is koud in je gezicht, zo

moet het ziinn nu, daar. En niemand die daar loopt, om dit te horen te voelen en te ruiken. Zullen we de fluwelen gordijnen sluiten of open laten. 


\section{AUTO-RETRATO}

Tal como as janelas altas desta casa, é assim que tem de ser, como agora.

É noite, lá em baixo alguns patos estão a nadar no lago, ali na relva o caminho começa a percorrer o seu lento arco através da floresta, vermelha como sangue velho, e acima da colina o céu, cinzento de neve, neblina e fumo. Grasna, grita, cheira a folhas húmidas e madeira a queimar, está frio no teu rosto, assim

deve ser lá, agora. E ninguém anda ali, para o ouvir, sentir e cheirar. Fechamos

as cortinas de veludo ou deixamo-las abertas? 
DEWULF, Jeroen. Quem encontra algo procurou mal: dez poemas de Rutger Kopland.

\section{WAT IS GELUK}

Omdat het geluk een herinnering is bestaat het geluk omdat tevens het omgekeerde het greview is, ik bedoel dit: omdat het geluk ons herinnert aan het geluk achtervolgt het ons en daarom ontvluchten wij het en omgekeerd, ik bedoel dit: dat wii het geluk zoeken omdat het zich verbergt in onze herinnering en

omgekeerd, ik bedoel dit: het geluk moet ergens en ooit zijn omdat wij dit ons herinneren en dit ons herinnert.

\section{O QUE É FELICIDADE}

Como a felicidade é uma recordação a felicidade existe porque também o seu contrário se verifica,

o que quero dizer é: como a felicidade nos faz lembrar a felicidade ela persegue-nos e por isso fugimos dela

e pelo contrário, o que quero dizer é: que nós procuramos a felicidade porque ela se esconde nas nossas recordações e 
pelo contrário, o que quero dizer é: deve existir a felicidade algures e em algum tempo pois lembramo-nos disto e isto faz-nos lembrar.

\section{BIBLIOGRAFIA}

CONINCK, Herman de (1970): "Rutger Kopland en de regelrechte grote gevoelens waar het om gaat", em: Kreatief, nr. 4/5. EKKERS, Remco (1997): "Dankzii de dingen", em: Lexicon van literaire werken, Amsterdam.

EVENPOEL, Stefaan (1989): "Alles op de fiets", em: : Lexicon van literaire werken, Amsterdam.

KOPLAND, Rutger (1988): Dankwoord bij de aanvaarding van de P.C. Hooftprijs, Amsterdam.

KOPLAND, Rutger (1999): Geluk is gevaarlijk: Een keuze uit de gedichten, Amsterdam.

KOPLAND, Rutger (2000): Gedichten, Amsterdam. 